\title{
Background on the Development Issues of Soil Erosion of Sloping Lands of Azerbaijan
}

\author{
RAE ZH Aliyev* \\ Institute of Pedology and Agrohimiii of ANAS, Russia \\ Received: 濞 August 05, 2018; Published: 酒 August 14, 2018 \\ *Corresponding author: RAE ZH Aliyev, Institute of Pedology and Agrohimiii of ANAS, Russia
}

\begin{abstract}
The article examines the issues of the possibility of studying the areas of development by soil erosion and its control. The study proved that the development of soil erosion is based on the forming impact of natural and anthropogenic factors. The degree of potential danger and the possibility of prevention, taking into account the preservation of the environmental situation in the foothills of the Upper Shirvan in the example of the Shamakhi district of the Republic of Azerbaijan, were studied. The main tasks of the study were a determination of the amount and degree of development of eroded and erosion-prone soils of the foothill zones carried out on the basis of soil erosion surveys of the farms of the republic.
\end{abstract}

Keywords: Erosion; Soil; Assessment of the degree of erosion environmentally hazardous; Anti-Erosion measures

\section{Introduction}

The territory of Azerbaijan is under environmental impacts the catchment of the Valley of the Caspian Sea. Here, environmental problems, which are the regional and depend on relations between States and for this reason, day after day they become strained. I must say that the soil exposed to erosion, forest plantations, mountain Grove, water sources, etc. natural education fail. In the geological and geographic region of the study has a rather complex structure, where the high mountains and steep slopes alternate Foothill areas and Plains, which in turn contributes to the development of a fairly Motley climate the diversity of vegetation. The complexity of the geomorphological structure, the presence of steep slopes, as well as anthropogenic forcing has a significant value of intensity of runoff, which in turn reinforces the development of erosive processes, resulting in created wide ravines, which are presented in the final stage beams, changing appearance of geomorphological region in General.

In the whole of Shirvan zone EM Shikhlinski [1] distinguishes 3 types of climate:

a) Warm-temperate characteristic of lowland regions in area with relatively mild winters;

b) Moderately warm moist type with a uniform distribution of rainfall throughout the year, covers part of the foothill zone and

c) Cold climate with wet winters, characteristic of the foothills and mountain areas.
Minimum air temperature $0.5^{\circ}$ with falls in January, and the maximum in $23.6^{\circ} \mathrm{c}$ in the month of July. The average soil temperature ranges from $-1^{0} \mathrm{p}-30.7^{\circ} \mathrm{c}$. Minimum temperature of soil in $-1^{0}$ with falls on January, maximum 30.00c (July) and August 30.70 months. Annual rainfall is $692 \mathrm{~mm}$, most of which falls in the months of April to June. The annual value of evaporation $825 \mathrm{~mm}$. The average relative air humidity is $71 \%$ kolebajaspo time of year from 59 to $87 \%$ [2]. It should be recognized that the results of the many fundamental and applied research on the development of soil erosion and erosion events proved that modern methods of study inevitably and naturally it was practiced always, however, it must be said that using new works mentioned themed, opens the next stage information experimental and applied research in the field of science, where the mixed with lime ways of dealing on prevent it by an integrated approach solutions challenge studies on development of erosion of natural habitats.

It is known that is not a complete list of information on soil erosion and responses at different administrative levels overlook the content beyond the Visual and other accounting materials researchers and university textbooks and may have substantial assistance to authors on many scientific and applied issues that could not be addressed fully in the Republic so far. Direction of study on soil erosion, their mapping and designing erosionpreventive, recommended for students is wide and diverse, and may be offered basic blocks (lines): soil erosion research- terminology, classification; 
a) The criteria used to determine the risk of erosion;

b) Assessment and mapping of erosion dangerous lands;

c) Mapping of eroded soils;

d) Protection of soil from erosion;

e) Designing erosion control activities;

f) Environmental, social and economic effectiveness of erosion control measures;

Status of research on the issue of protecting the soil from erosion in Azerbaijan and other countries of the world. The natural and climatic conditions of the Republic due to the water balance deficit contributes to development and erosion, deflation, and that require specific, progressive methods of development here soil, crops, land reclamation and protection without having small the Land Fund. It should be noted that in the Republic basic arrays suitable for irrigated agricultural land use is already a component of 1.410 million ha have been mastered and further expansion of arable land is only possible due to the development of less productive land that and requires excessive protection from soil erosion on the reclaimed lands, maintaining and enhancing soil fertility is of great importance for the country.

In the process of realization of scientific research conducted by the authors in the Institute Erosion and irrigation NANA on the direction of research in their monographs soil erosion is represented as a function of the natural and anthropogenic factors and its environmental consequence. The authors assumed that each science requires some precision and clarity of concepts and achievements of new results continuously improved control measures and classification of objects. These issues have engaged many scholars, so for example: AN Zavarickij (1947); Sobolev SS (1948), KA Alekperov DA (1950-1970), Khalilov M Kh (1972-1989), AA Ibrahimov (1967-2010), Shvebs G (1977), Belgibaev ME (1970), Budagov BA (1953-2006), Zaslavsky (1972-1979), G Sh Mamedov
(1980-2002), Aliyev BH (1990-2016); etc., in the writings of which terms, derived from the word erosion as well as the concept of water and wind erosion treated very extensively and definitely not always, and, in this regard, there are many examples of their divisive the interpretation.

From among the authors published their monographs are reasonably M Zaslavsky, KA Alekperov, BH Aliyev who, instead of widespread term water erosion recommends the use of the term to refer to soil erosion as flushing, so soil erosion and surface run-off water flows, temporary and term deflation (confront wind) instead of wind erosion, which precisely captures the essence of the phenomenon [3]. Listed in the reportable materials numerous studies and monographs authors scope and geography of soil degradation, the economic damage caused by erosion of the horrifying. Carried out major structural changes as a result of the land reforms in agriculture initiated in Azerbaijan starting with the year 1990, led to the reduction of agricultural land, the withdrawal from agricultural use vast areas of arable land and grassland degradation, covered by huge economic and environmental damage and the threat to the very existence of the soil as the principal means of production and irreplaceable component of the biosphere.

It is known that patterns of manifestations of land degradation related to climatic, lithological-geomorphological particularities, as well as the intensity of manifestation of anthropogenic influence. The Republic of Azerbaijan, the insufficiency of knowledge, characterized by large areas of arable land with very low humus content, high acidity, scarcity of phosphate soil regime. The results of the study determined that in Azerbaijan land occupies sklonovye ha 3236 square. Land distribution in natural and economic zones of the Republic on relief conditions placed as follows (Table 1) [1,3,4]. Thus, the limited land resources is forcing even plow steep slopes. It is believed that slopes from $3^{0}$ to $15^{0}$ (biases $0.05-0.25$ ) are flat, from 0 to $1520^{\circ}(0.25-0.35)$ - transition to steep, $20^{\circ}$-steep. On the basis of the results of research and other scientists ought to be that of this boundary slopes, suitable for irrigation 216 thousand.

Table 1: Land distribution in natural and economic areas of the Republic on relief conditions.

\begin{tabular}{|c|c|c|c|c|c|}
\hline \multirow{2}{*}{ Natural-Economic zones } & \multirow{2}{*}{ Suitable for Orosz. Earth pouslovijamrelefa } & \multicolumn{4}{|c|}{ Including slopes } \\
\hline & & $\nabla 0.05$ & $0.05+0.10$ & +0.200 .10 & +0.400 .20 \\
\hline 1 & 2 & 3 & 4 & 5 & 6 \\
\hline Ganja-Kazakh & 427.50 & 251.0 & 72.8 & 63.70 & 40.00 \\
\hline Shirvan & 680.80 & 522.6 & 50.0 & 66.10 & 42.10 \\
\hline Karabakh-Milskaja & 749.00 & 567.6 & 80.20 & 47.40 & 53.80 \\
\hline $\begin{array}{l}\text { Waterless Mugano- } \\
\text { Saljanskaja }\end{array}$ & 429.8 & 402.4 & 2.8 & 17.1 & 7.5 \\
\hline Shaki-Zakatalskaja & 322.7 & 236.5 & 42.7 & 23.8 & 19.7 \\
\hline Lankaran & 81.5 & 79.5 & 2.0 & - & - \\
\hline Absheron & 52.7 & 31.1 & 21.6 & - & - \\
\hline Cuba-Xacmaz & 203.5 & 179.1 & 24.4 & - & - \\
\hline Upper Garabag & 133.7 & 24.7 & 27.8 & 37.6 & 43.4 \\
\hline Nakhchivan & 154.2 & 95.3 & 38.0 & 11.2 & 9.7 \\
\hline Total Republic & 3235.4 & 2390.0 & 362.3 & 266.9 & 216.2 \\
\hline
\end{tabular}


Hectares are located on steep slopes, 629 thousand hectares is on sites with slopes ranging from 0.05 to 0.20 and 2390 thous. HA-shallow areas with slopes $₫ 0.05$. To conclude on the slopes of $15-20^{\circ}$ place gardens and vineyards. Often sklonovye lands in 30$40^{0}$ degrees or greater, are used for vineyards with the direction of the rows along the slope, posing a dire condition for exploitation of agricultural machines and enhanced flushing topsoil in the aisles. Therefore, the author considers when laying new vineyards and orchards should not go on seemingly a more economical way of bookmarks in the direction of the slope. There is also use of steep slopes under crops grain and forage crops [3-5].

Ploughing and tillage on such areas run along the slope, which contributes to the flushing of soil and a sharp decline in its fertility. Long-term systematic not a legitimate use of chemical plant protection products in the region, as the years of Soviet power, and now especially pesticides, is one of the main problems in the agricultural zone of the Republic as Lip-Hachmasskoj, Ganja-
Gazakh, Upper Shirvani and Holding. Pollution of the soil here has a negative impact on plants, reduce the harvest of crops and the potential loss 1 soil fertility. Along with the pollution of ecosystems affected by the negative consequences for people and livestock in the region.

Environmental pollution has become one of the most important Wednesday challenges, special role where belongs to the heavy metals that have the ability to accumulate in soils and through them get into foods while promoting and soil degradation. Zoning of the territory of the Republic on irrigation technique and degree of soil erosion in republics showed that 14 districts have a tense situation, in which there is a risk the withdrawal of arable land here due to the intensive use of in view of the complete degradation of soils. In Azerbaijan are found all types of erosion (incl. water, mudflow, wind, surface, line, etc.) the susceptibility of soil erosion in mountain areas of Azerbaijan are listed in the Table 2.

Table 2: Exposure to soil erosion in mountain areas of Azerbaijan.

\begin{tabular}{|c|c|c|c|c|c|}
\hline \multirow[b]{2}{*}{ Areas } & \multirow[b]{2}{*}{ Total area in th. ha } & \multicolumn{4}{|c|}{ Including exposure to erosion } \\
\hline & & $\begin{array}{c}\text { Not podverzh. } \\
\text { ths. ha,\% }\end{array}$ & $\begin{array}{l}\text { Little } \\
\text { ha, } \%\end{array}$ & $\begin{array}{c}\text { medium } \\
\text { ha,\% }\end{array}$ & $\begin{array}{c}\text { Strongly } \\
\text { ha,\% }\end{array}$ \\
\hline Dashkesan & 90.3 & $23.3 / 25.8$ & $18.3 / 20.3$ & $25.6 / 28.3$ & $23.1 / 25.6$ \\
\hline Gədəbəy & 150.3 & $73.6 / 49.0$ & $20.1 / 13.4$ & $\backslash 29.829 .8$ & $26.8 / 27.8$ \\
\hline Lachin & 124.3 & $48.4 / 38.9$ & $27.2 / 21.9$ & $18.9 / 15.2$ & $29.8 / 24.0$ \\
\hline Lachin & 166.5 & $56.7 / 34.1$ & $26.3 / 15.8$ & $36.7 / 22.0$ & $46.8 / 28.1$ \\
\hline Kubadly & 79.8 & $25.7 / 33.5$ & $6.9 / 8.6$ & /28.736.0 & $17.5 / 21.9$ \\
\hline Zangilan & 72.5 & $24.6 / 33.9$ & $16.4 / 22.6$ & $14.6 / 20.2$ & $16.9 / 23.3$ \\
\hline Lerik & 136.5 & $43.6 / 32.2$ & $19.4 / 14.3$ & $27.8 / 20.5$ & $44.7 / 33.0$ \\
\hline Yardimli & 12.5 & $25.1 / 34.6$ & $12.6 / 17.4$ & $10.6 / 14.6$ & $24.2 / 34.4$ \\
\hline $\begin{array}{l}\text { Mountain part } \\
\text { Goranboja }\end{array}$ & $57.6 / 20.8 / 19.5$ & $7.7 / 36.1$ & 33.9 & 13.4 & $9.6 / 16.6$ \\
\hline Julfa & 99.4 & $9.9 / 10.0$ & $16.3 / 16.4$ & $25.3 / 25.5$ & $47.9 / 48.1$ \\
\hline Shahbuz & 81.4 & $61.1 / 19.8$ & $5.4 / 6.6$ & $15.7 / 19.3$ & $14.2 / 54.3$ \\
\hline Ordubad & 92.4 & $7.0 / 7.6$ & $9.5 / 10.6$ & $13.5 / 14.6$ & $62.1 / 67.2$ \\
\hline Absheron & 535 & $57.5 / 10.7$ & $116.8 / 21.8$ & $165.5 / 30.9$ & $195.5 / 36.6$ \\
\hline
\end{tabular}

As can be seen from the table, the most common is water erosion, which develops in mountain regions more intensively. Mountain soil in this and other exposed to erosion, which covers $51.0-92.4 \%$ land area. The Shahbuz, and Also areas of soil subjected to strong erosion and, respectively, accounted for 54.3 and $67.2 \%[3,4]$. You can enlarge irrigated lands up to $1235 \mathrm{ha}$. The above-mentioned mountainous areas, thanks to the collection of mud water in small ponds, over 1300 hectares of wet or unaffected farming soils hold watering, which serves to protect the mudflow and irrigation erosion in these areas. Furthermore, by reducing soil erosion, introduction of a number of events, w. h. ensure the soil in sufficient quantities of mineral fertilizers in these areas can be achieved production of 35.0 thousand tons of wheat, 12.0 thousand tons of tobacco, 10-15 thousand tons of vegetables, 95100 thousand tons of potato, as well as through improved forage base significantly improve livestock production $[3,4,6]$.
On the mountain and Foothill regions on sloping lands of Azerbaijan using newly developed technological means of irrigation, us has been implemented large amount of long-term research work under the supervision of BH Aliyev [3]. Given the above, it is recommended for mountain and Foothill areas following irrigation methods:
a) Furrow with slit;
b) Spray a low intensity rain sivnostju;
c) Small dispersion moisturising and without combining with sprinkler systems;

d) Drip irrigation, etc.

Irrigation on furrows with slit area $\nabla 0.03$. for other crops in the conditions of surface irrigation method is not recommended 
because wasteful water consumption. It should be noted that the establishment and development of new progressive methods of irrigation, irrigation erosion is an exception to save irrigation water and not violate environmental protection Wednesday. From the above it follows that while mastering the slopes not only in Azerbaijan, but also in countries throughout the world requires a cautious approach to the choice of irrigation technique and technology recommended for irrigation of cultivated crops on land On slopes. conclusion on the slopes of 15-200 place gardens and vineyards. Often sklonovye lands in 30-400 degrees or greater, are used for vineyards with the direction of the rows along the slope, posing a dire conditions for the exploitation of agricultural machines and enhanced flushing topsoil the aisles [2,7].

Therefore, the author considers when laying new vineyards and orchards should not go on seemingly a more economical way of bookmarks in the direction of the slope. There is also use of steep slopes under crops grain and forage crops. To meet this challenge requires a differentiation of lands for their natural potential and degree of erosion and then define a set of measures to put an end to degradation and restoration of soil fertility with subsequent zoning of the territory of the Republic according to the degree of erosion with obligatory taking into account all factors affecting the State and land use in different types of soils of the Republic
[2-4]. It must be recognized, however, that the effectiveness of our measures of erosion control and the prevention of erosion risk are complex defenses, promotes regulation of runoff, soil protection from flushing, erosion, However, the restoration and improvement of soil eroded and the involvement of eroded land in the rational use of the agriculture Republic $[8,9]$.

\section{References}

1. Shyhlinskij EM Climate in Azerbaijan, Baku, 1968, with 341.

2. Mamedov RG Agrofizicheskaja characteristics of soil priaraksinskoj stripes, 1970 with 321.

3. Aliyev BH, Aliyev ZH (2000) Eit and erosion Problems in Azerbaijan and ways of its solution. Izd-vo Zia-CPI, Nurlan.

4. Mamedov G Sh (2000) Land reform in Azerbaijan: Legal, scientific and environmental issues, pp. 371.

5. Babayev MP, Jafarov AM (2017) Modern pochennyj cover of the Greater Caucasus, Baku, pp. 344.

6. Aliyev GA (1978) Soils of the big Caucasus within the Azerbaijan SSR, Baku, Elm, pp. 157.

7. (2007) Biodiversity and climate diversity. AGI, UNEP.

8. Vernadsky VI (1908) Works on the General history of Science.

9. VE Flint (2002) Conservation and restoration of biodiversity. M IZD Scientific and educational-methodical Center, pp. 282.
ISSN: 2574-1241

DOI: 10.26717/BJSTR.2018.08.001585

RAE ZH Aliyev. Biomed J Sci \& Tech Res

(C) This work is licensed under Creative

Submission Link: https://biomedres.us/submit-manuscript.php

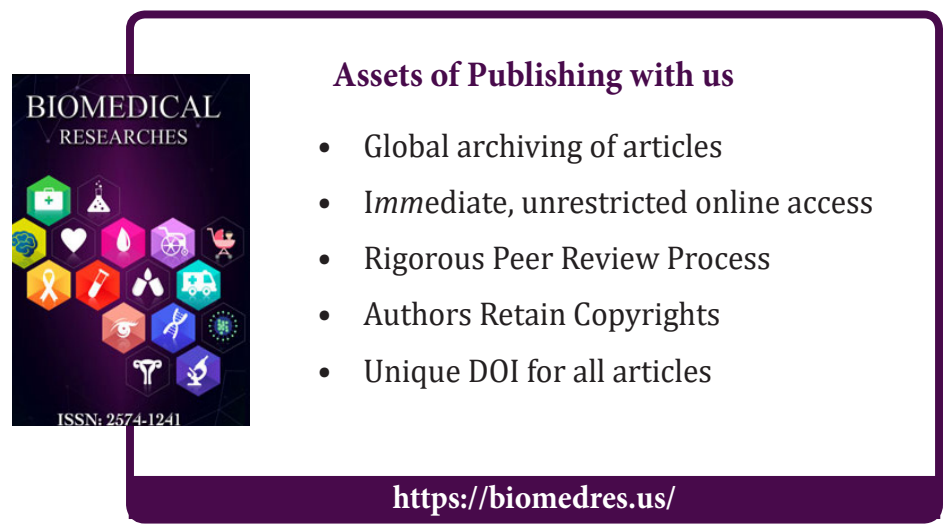

